\title{
Pouteria torta: a native species of the Brazilian Cerrado as a bioindicator of glyphosate action
}

\author{
P. F. Batista ${ }^{a}$, A. C. Costa ${ }^{a}$, C. A. Megguer ${ }^{b}$, J. S. Lima ${ }^{a}$, F. B. Silva ${ }^{a}$, D. S. Guimarães ${ }^{a}$, \\ G. M. Almeida a and K. J. T. Nascimento ${ }^{a}$ \\ ${ }^{a}$ Laboratory of Ecophysiology and Plant Productivity, Department of Agronomy, Instituto Federal Goiano - IF Goiano, \\ Campus Rio Verde, CEP 75901-970, Rio Verde, GO, Brazil \\ bPlant Physiology Laboratory, Department of Agronomy, Instituto Federal Goiano - IF Goiano, Campus Morrinhos, \\ Morrinhos, CEP 75650-000, GO, Brazil \\ *e-mail: alcarcos@pq.cnpq.br
}

Received: May 23, 2016 - Accepted: October 9, 2016 - Distributed: May 31, 2018

(With 7 Figures)

\begin{abstract}
In Brazil, the expansion of agricultural activity and the associated indiscriminate use of herbicides such as glyphosate is directly related to the loss of biodiversity in the Cerrado. The identification of plant species as bioindicators of herbicide action, especially species native to the area, can help in monitoring the impacts of xenobiotics in the remaining Cerrado. Thus, this study was designed to evaluate the possible use of the native Cerrado species Pouteria torta as a bioindicator of glyphosate action via changes in physiological performance. At 16 months after sowing, the effect of

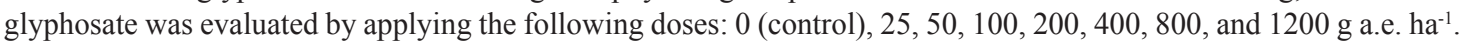
In response to glyphosate, $P$. torta exhibited reductions in photosynthesis and chloroplastid pigment content, as well as accumulation of shikimic acid and the occurrence of chlorosis and necrosis. These changes demonstrate the high sensitivity of $P$. torta to glyphosate and its potential for use as a bioindicator of this herbicide.
\end{abstract}

Keywords: phytotoxicity, photosynthetic processes, biomarker, guapeva, herbicide.

\section{Pouteria torta: espécie native do Cerrado Brasileiro como bioindicadora da ação do glyphosate}

\begin{abstract}
Resumo
No Brasil, a expansão da atividade agrícola, aliada a utilização indiscriminada de herbicidas como o glyphosate, possui relação direta com a perda da biodiversidade no Cerrado. A identificação de espécies vegetais bioindicadoras da ação de herbicidas, particularmente as nativas do Cerrado, pode auxiliar em processos de monitoramento dos impactos desse xenobiótico nas remanescentes do Cerrado. Assim, este estudo foi projetado para avaliar o possível uso de Pouteria torta, espécie nativa do cerrado, como bioindicadora da ação do glyphosate via mudanças na sua performance fisiológica. Após 16 meses de semeadura, o efeito do glyphosate foi avaliado quando aplicadas as seguintes doses: 0 (controle), $25,50,100,200,400,800$ e $1200 \mathrm{~g}$ e. a. ha-1. Em reposta ao glyphosate, as plantas de $P$. torta apresentaram redução na sua performance do processo fotossintético e no conteúdo de pigmentos cloroplastídicos, além do acúmulo de ácido chiquímico e da ocorrência de cloroses e necroses. Essas alterações demonstram a alta sensibilidade de $P$. torta ao glyphosate, o que potencializa a sua utilização como bioindicadora da ação desse herbicida.
\end{abstract}

Palavras-chaves: fitotoxidade, processos fotossintéticos, biomarcador, guapeva, herbicida.

\section{Introduction}

The Cerrado is one of the main global hotspots of flora diversity and the second largest of such areas in Brazil (Myers et al., 2000; Silva et al., 2006; Silva, 2010). However, its natural vegetation has been extensively deforested for agricultural use (Françoso et al., 2015; Carvalho et al., 2014). For example, in the central western area of Brazil, there have been losses of $53 \%$ of the Cerrado due to intense agricultural development (Beuchle et al.,
2015). The expansion and development of Brazilian agriculture is largely associated with intensive use of pesticides, especially herbicides (Procópio et al., 2009; Mancuso et al., 2011). The indiscriminate use of herbicides has had one of the main impacts on the health of organisms (Marris, 2005; Franco-Bernardes et al., 2015). There is consensus about the negative impact of herbicide exposure on non-target organisms, especially by drift processes 
(Power et al., 2013; Boutin et al., 2014; Marwitz et al., 2014; Egan et al., 2014). However, there are few studies about efficient methods for monitoring the impact of herbicides on vegetation in the Cerrado (Boutin et al., 2012). The scarcity of such studies is another factor that threatens the biodiversity of this biome.

Biomonitoring has recently attracted attention among methods for evaluating the environmental impact of herbicides (Boutin et al., 2014; Prasad et al., 2015). Reversible and irreversible changes in plant metabolism can be used as bioindicators for the action of xenobiotics (Boutin et al., 2014). Some of the biomarkers used in biomonitoring are the changes in the structure of nucleic acids (Wang et al., 2016), chlorophyll $a$ fluorescence, gas exchange (Duke et al., 2003; MacFarlane, 2003), chloroplastid pigment content (Prasad et al., 2015), metabolites, proteins (Schrübbers et al., 2014; Dayan et al., 2015; Hattab et al., 2016), and the occurrence of chlorosis and necrosis in leaves (De-Temmerman et al., 2004).

The glyphosate (N-phosphonomethyl-glycine) causes damage to a wide variety of species (Simmons, 2013), whereas it is systemic and nonselective (Zhao et. al., 2011). This herbicide is used on a large scale and with high frequency (Sihtmäe et al., 2013; Bohn et al., 2014). Glyphosate has a broad spectrum and acts by inhibiting the action of 5-enolpyruvylshikimate-3-phosphate synthase (EPSPs), which is considered a key enzyme in the pathway of shikimic acid, a biosynthetic precursor of the aromatic amino acids phenylalanine, tryptophan, and tyrosine (Dayan and Zaccaro, 2012). This herbicide is phloem-mobile and can be rapidly translocated via symplasts to all parts of the plant (Yamada and Castro, 2007; Machado et al., 2010), which enhances its toxic action on all plant tissue.

Considering the ample evidence of the toxic effects of glyphosate to organisms (Franco-Bernardes et al., 2015), it is necessary to study efficient methods of managing of the health of Cerrado areas exposed to this herbicide. Particularly important is the selection of highly responsive and specific biomarkers in plants as potential bioindicators. A bioindicator species is any species which is sensitive to a pollutant, showing alterations at physiological and biochemical levels, in addition to visual symptoms (Nunes and Vidal, 2009).

Pouteria torta (Mart.) Radlk., belonging to the family Sapotaceae, is a species native to the Cerrado. It is an arboreal species with great potential for biomonitoring of herbicide action in the Cerrado since it has wide distribution (Perfeito et al., 2005), which increases its exposure to the drift process of pesticides. This species is popularly known for "guapeva", "curriola", "açá ferro", "abiu do cerrado" and "grão de galo" (Perfeito et al., 2005). It is a lactescent plant, with 8 to $14 \mathrm{~m}$ tall, and it has a fluted trunk with a diameter of 30 to $40 \mathrm{~cm}$. It annually produces an abundant fruit load, which is used for human consumption and the peel is used as an anti-dysentery medicine (Perfeito et al., 2005). Its seeds have rapid emergence and also antifungal and insecticide activity (Boleti et al., 2007). Therefore, this study evaluated the hypothesis that $P$. torta is sensitive to herbicide glyphosate, which could be monitored by changes in photosynthetic metabolism. These changes could be used to classify $P$. torta as a potential phytoindicator of glyphosate action in the Cerrado.

\section{Material and Methods}

\subsection{Plant growth and experimental conditions}

Fruits were collected from a single specimen of P. torta at Fazenda Santo Antonio, Iporá, Brazil (16 26' 29' S, 51 7' $11^{\circ}$ ' W). The seeds were obtained and sown in sand. After 60 days, seedlings were transferred to polyethylene pots containing $10 \mathrm{Kg}$ of a substrate consisting of typical dystrophic red oxisol and sand (2:1). This substrate has the following chemical characteristics: $\mathrm{pH}$ 6.3 (in water); $0.7 \mathrm{mg} \mathrm{dm}^{-3} \mathrm{P} ; 8 \mathrm{mg} \mathrm{dm}^{-3} \mathrm{~K} ; 240 \mathrm{mg} \mathrm{dm}^{-3} \mathrm{Ca}$, $24.3 \mathrm{mg} \mathrm{dm}^{-3} \mathrm{Mg}, 174 \mathrm{mg} \mathrm{dm}^{-3} \mathrm{H}+\mathrm{Al}, 11 \mathrm{~g} \mathrm{~kg}^{-1}$ organic matter, and $68 \%$ base saturation. Based on this chemical analysis, each pot was fertilized with $1.525 \mathrm{~g}$ of urea, $1.175 \mathrm{~g}$ of $\mathrm{K}_{2} \mathrm{O}, 6.9 \mathrm{~g}$ of $\mathrm{P}_{2} \mathrm{O}_{5}$, and $0.4 \mathrm{~g}$ of micronutrients (Fritted Traced Elements ${ }^{\circledR}$, São Paulo, Brazil).

The experiment was conducted in April 2013 in a climatized greenhouse at the Laboratory of Plant Ecophysiology and Productivity of the Federal Institute of Goiás, Rio Verde Campus. The temperature and relative humidity of the greenhouse were monitored during the experimental period using a weather station (WATCH DOG - Weather Station, Spectrum Technologies, Inc., Aurora, IL, USA).

\subsection{Treatment application}

The effect of glyphosate [Roundup Transorb ${ }^{\circledR}$ isopropylamine, $480 \mathrm{~g} \mathrm{~L}^{-1}$ acid equivalent (g e. a. ha-1) Monsanto Agricultural São José dos Campos, SP] was evaluated using the following doses: 0 (control), 25, 50, $100,200,400,800$, and $1200 \mathrm{~g}$ a.e. $\mathrm{ha}^{-1}$. In general crops, glyphosate rates applied vary between 720 and $1700 \mathrm{~g}$ e. a. ha $^{-1}$. The herbicide was applied using a backpack sprayer (Herbicat ${ }^{\circledR}$ Catanduva, Brazil) with constant pressure maintained by compressed $\mathrm{CO}_{2}$, a boom sprayer with four spray tips, and an extended-range flat spray tip (Teejet XR110/02VP). The working pressure was $5 \mathrm{kgf} \mathrm{cm}^{-2}$, resulting in a spray solution volume of $200 \mathrm{~L} \mathrm{ha}^{-1}$.

\subsection{Physiological determination}

Gas exchange and chlorophyll $a$ fluorescence were measured on the second fully expanded pair of leaves in the period between $8 \mathrm{~h} 00 \mathrm{~min}$ and $10 \mathrm{~h} 30 \mathrm{~min}$. Chlorophyll $a$ and $b$ and total chlorophyll were measured in the same leaf areas where leaf gas exchange and chlorophyll $a$ fluorescence were determined. A total of 10 measurements were performed at 2, 6, 24, 48, 72, 96, 120, 144, 168, and 240 hours after application (HAA) of glyphosate. The measurement times were chosen to detect early physiological changes that may be specific to the effects of glyphosate. 
2.3.1. Measurements of gas exchange and chlorophyll a fluorescence

Gas exchange was assayed to determine the photosynthetic rate $\left(A, \mu \mathrm{mol} \mathrm{m} \mathrm{m}^{-2} \mathrm{~s}^{-1}\right)$, transpiration rate $\left(E, \mathrm{mmol} \mathrm{m} \mathrm{m}^{-2} \mathrm{~s}^{-1}\right)$, stomatal conductance $\left(\mathrm{gs}, \mathrm{mol} \mathrm{H} \mathrm{O} \mathrm{m}^{-2} \mathrm{~s}^{-1}\right)$, and the ratio of internal $\mathrm{CO}_{2}$ concentrations to external concentrations $(\mathrm{Ci} / \mathrm{Ca})$. Measurements were performed using a portable open-system infrared gas analyzer (LI-6400, LI-COR Inc., Lincoln, NE, USA) under an ambient $\mathrm{CO}_{2}$ concentration and room temperatures of 24 to $26^{\circ} \mathrm{C}$. All of the measurements were conducted under artificial saturating photon irradiance $\left(1,000 \mu \mathrm{mol} \mathrm{m} \mathrm{m}^{-2} \mathrm{~s}^{-1}\right)$ at the leaf level.

The chlorophyll $a$ fluorescence parameters were determined using a portable fluorometer with a modulated pulse MINI-PAM (Walz ${ }^{\circledR}$, Effeltrich, Germany) equipped with a leaf-clip 2030-B (Bilger et al., 1995; Rascher et al., 2000). The leaf was dark-adapted for $30 \mathrm{~min}$ and exposed to a weak far-red light pulse $\left(0.5 \mu \mathrm{mol} \mathrm{m} \mathrm{m}^{-2} \mathrm{~s}^{-1}\right)$ for the determination of the initial fluorescence $\left(\mathrm{F}_{0}\right)$. A saturating light pulse $\left(0.8 \mathrm{~s} ; 2,400 \mu \mathrm{mol}\right.$ (photons) $\left.\mathrm{m}^{-2} \mathrm{~s}^{-1}\right)$ was then applied to estimate the maximum emitted fluorescence $\left(\mathrm{F}_{\mathrm{m}}\right)$. Using these parameters, the maximum quantum yield of photosystem II (PSII) was calculated (Fv/Fm) (Van Kooten and Snel, 1990).

In light-adapted leaves, the steady-state fluorescence yield $\left(\mathrm{F}_{\mathrm{s}}\right)$ was measured after a saturating white light pulse $\left(2,400 \mu \mathrm{mol} \mathrm{m} \mathrm{m}^{-2} \mathrm{~s}^{-1}, 0.8 \mathrm{~s}\right)$ was applied to achieve the light-adapted maximum fluorescence $\left(\mathrm{F}_{\mathrm{m}}{ }^{\prime}\right)$. The actinic light was then turned off, and far-red illumination was applied $\left(2 \mu \mathrm{mol} \mathrm{m} \mathrm{m}^{-2} \mathrm{~s}^{-1}\right)$ to measure the light-adapted initial fluorescence $\left(\mathrm{F}_{0}{ }^{\prime}\right)$. Using these parameters, the effective quantum yield of PSII ( $\Delta \mathrm{F} / \mathrm{Fm}$ ') was calculated (Genty et al., 1989). $\Delta \mathrm{F} / \mathrm{Fm}$ ' was used to estimate the apparent electron transport rate (ETR) (Bilger et al., 1995; Laisk and Loreto, 1996), and non-photochemical quenching (NPQ) was calculated according to Bilger and Bjorkman (1990).

\subsubsection{Measurements of photosynthetic pigment} contents

Chlorophyll $a$ and $b$ and total chlorophyll were determined using a portable meter (ClorofiLOG1030 ${ }^{\circledR}$, Falker $^{\circledR}$, Porto Alegre, Brazil) and expressed as the Clorofilog index.

\subsubsection{Determination of shikimic acid concentration}

Eight leaf discs with a radius of $6 \mathrm{~mm}(\sim 25 \mathrm{mg})$ were sampled from the second leaves from the apical meristem of each plant at 2, 6, 24, 48, 72, 120, 168, and 216 HAA to determine the concentration of shikimic acid. The leaf disc samples were kept in liquid $\mathrm{N}_{2}$ during sampling and then stored at $-80{ }^{\circ} \mathrm{C}$ until further analysis. Shikimic acid was extracted according to Singh and Shaner (1998) with some modifications. The frozen samples were ground in microtubes containing $\mathrm{HCl}(0.25 \mathrm{~N})$ at a ratio 1:10 (tissue mass $(\mathrm{g})$ : volume of $\mathrm{HCl} 0.25 \mathrm{~N}(\mathrm{ml})$ ). The extract was centrifuged at $15,000 \times g$ for $25 \mathrm{~min}$ at $4{ }^{\circ} \mathrm{C}$. After centrifugation, $30 \mu \mathrm{L}$ of the supernatant was reacted with $500 \mu \mathrm{L}$ of periodic acid (1\%) for $45 \mathrm{~min}$ in a boiling water bath at $37^{\circ} \mathrm{C}$, and then $500 \mu \mathrm{L}$ of sodium hydroxide $(1 \mathrm{~N})$ and $300 \mu \mathrm{L}$ of glycine $(0.1 \mathrm{M})$ were added. The absorbances were measured at $380 \mathrm{~nm}$ in a spectrophotometer (UV-VIS Evolution 60S Thermo Fischer Scientific $^{\circledR}$, Madison, USA). The molar extinction coefficient of $4.76 \times 10^{4} \mathrm{M}^{-1} \mathrm{~cm}^{-1}$ was used to calculate the shikimc acid concentration (Gaitonde and Gordon, 1958), which was expressed in $\mathrm{mg} \mathrm{g}^{-1}$ of fresh weight (FW).

\subsubsection{Analysis of visual symptoms in P. torta}

To registry of visual symptoms resulting from application of glyphosate in P. torta, leaves were photographed at 240 HAA using a 14-megapixel digital camera (Finepix SL 300) with 30x optical zoom and a high-resolution LCD.

\subsection{Experimental design}

The experiment was carried out in a randomized block experimental design and four replications. The following experimental designs were considered for analysis of variance (ANOVA): (1) an $8 \times 10$ factorial experiment (doses $\times$ evaluation times) for the gas exchange, chlorophyll $a$ fluorescence, and photosynthetic pigment content (320 experimental units in total) and (2) an $8 \times 8$ factorial experiment (doses $\times$ evaluation times) for the shikimic acid concentration (256 experimental units). Regression models were fitted to the data using the software SAEG 9.0 (General Statistical Analysis System-Sistema de Análises Estatísticas Gerais, Federal University of Viçosa, Viçosa, Brazil). Graphics were constructed using SigmaPlot V.10 software (SPSS Inc., USA).

\section{Results}

\subsection{Microclimate conditions}

During the experimental period, the temperature and relative humidity varied, respectively, between $23{ }^{\circ} \mathrm{C}$ and $28{ }^{\circ} \mathrm{C}$ and of $61 \%$ and $80 \%$. These few variations indicates that there was no overlap of abiotic stress in the plants evaluated, meaning that the results were due to glyphosate action.

\subsection{Gas exchange and chlorophyll a fluorescence}

The photosynthetic rate $(A)$ and stomatal conductance ( $g s)$ decreased in response to the increasing doses of glyphosate and evaluation times. The glyphosate effects in $A$ and $g s$ were more pronounced at 240 and 72 HAA, respectively, mostly in plants treatments with the dose of $1,200 \mathrm{~g}$ a. e. $\mathrm{ha}^{-1}$, with decreases of $70 \%$ in $A$ and $75 \%$ in gs (Figure 1A and 1B). The transpiration rate $(E)$ decreased in response to the independent effects of the doses of glyphosate and evaluation times (Figure 2A and 2B), while internal to external $\mathrm{CO}_{2}$ concentration ratio $(\mathrm{Ci} / \mathrm{Ca})$ increased solely in response to the doses of glyphosate (Figure 2C and 2D). In particular, decreased of 57\% in $E$ occurred in the plants treatments with 1,200 $\mathrm{g}$ a. e. ha $^{-1}$ compared to their non-herbicide counterparts (Figure 2A and 2B). In response of the increasing doses of glyphosate, $\mathrm{Ci} / \mathrm{Ca}$ reached increase by more $53 \%$ at 240 HAA (Figure 2C and 2D). 


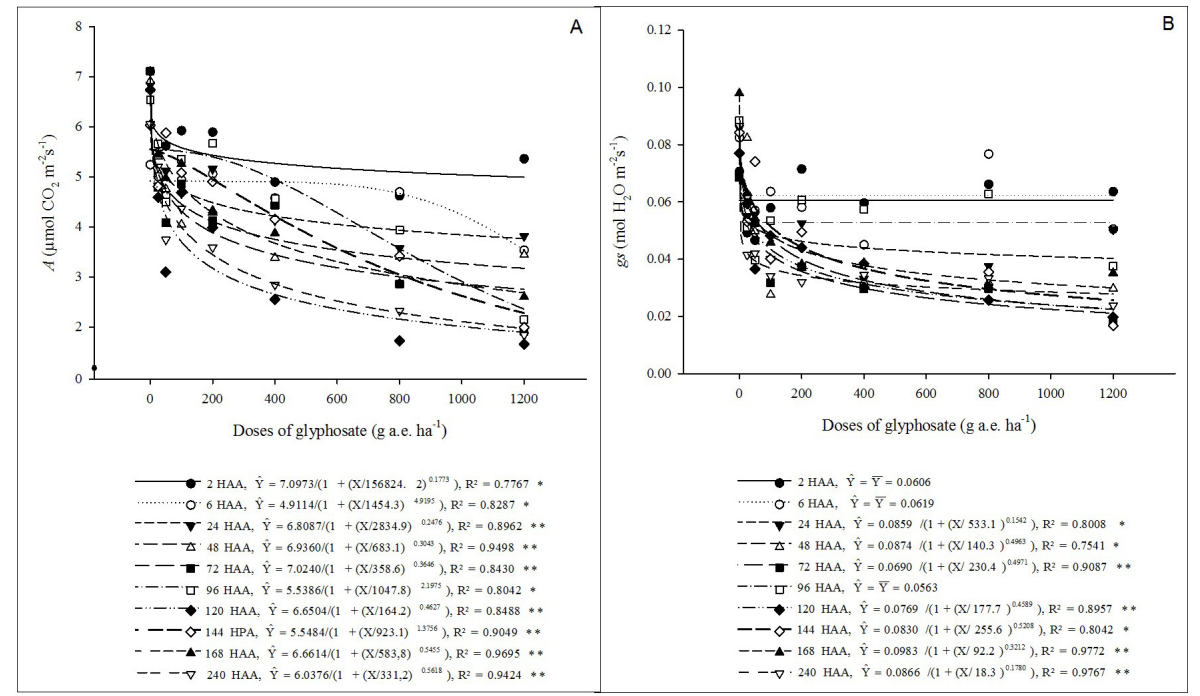

Figure 1. Photosynthetic rate $(A ; \mathrm{A})$ and stomatal conductance $\left(g_{s} ; \mathrm{B}\right)$ determined on the leaves of Pouteria torta plants in respose of the interaction between different doses of glyphosate and evaluated and evaluated at ten different times (HAA). Values are averages $n=4$. Significant by factorial analysis $(* \mathrm{p} \leq 0.05 ; * * \mathrm{p} \leq 0.01)$.

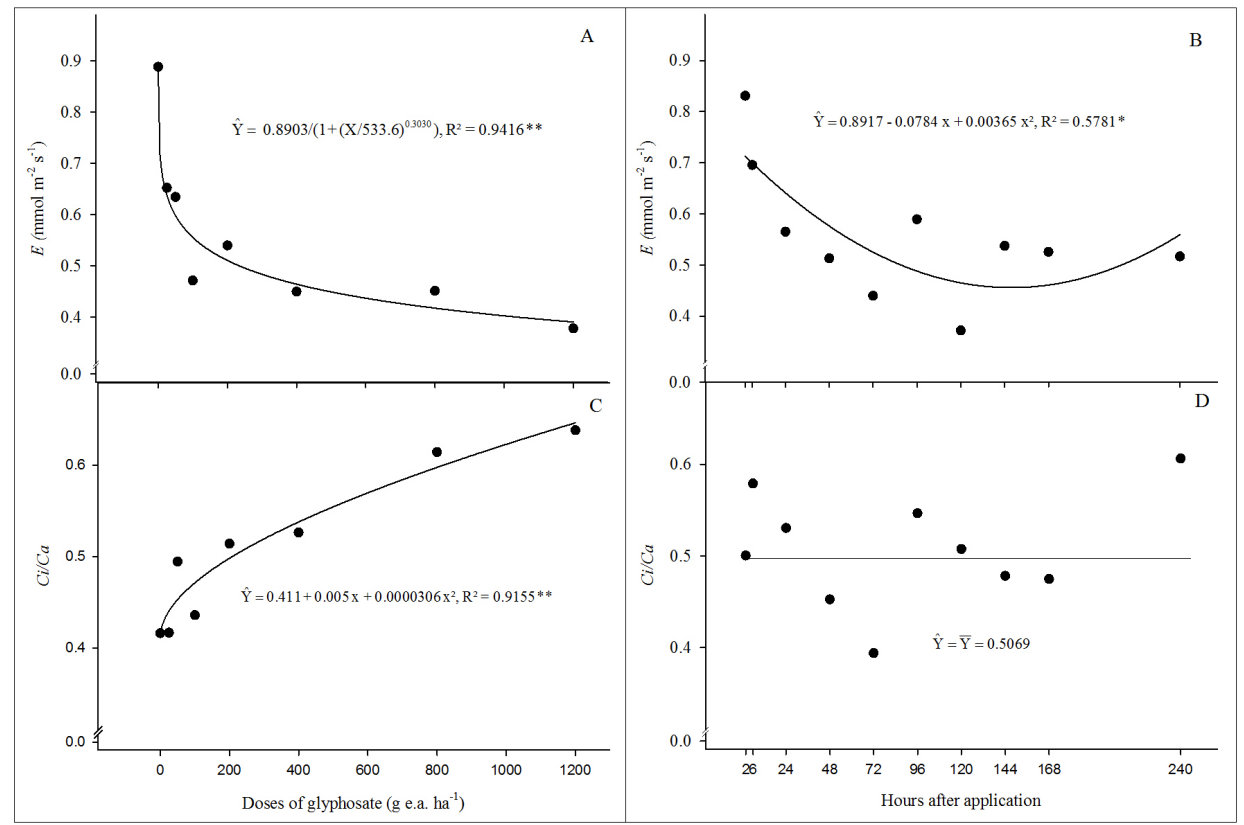

Figure 2. Transpiration rates $(\mathrm{E} ; \mathrm{A}, \mathrm{B})$ and internal to external $\mathrm{CO}_{2}$ concentration ratios $(\mathrm{Ci} / \mathrm{Ca} ; \mathrm{C}, \mathrm{D})$ determined on the leaves of Pouteria torta plants treated with different doses of glyphosate $(n=32)$ and evaluated at ten different times (HAA) $(n=40)$. Significant by factorial analysis $(* \mathrm{p} \leq 0.05 ; * \mathrm{p} \leq 0.01)$.

The variables of maximum quantum yield of photosystem II (PSII) $(F v / F m)$, effective quantum yield of PSII ( $\triangle \mathrm{F} / \mathrm{Fm}$ '), apparent electron transport rate (ETR) and and non-photochemical quenching (NPQ) exhibited pronounced changes in response to the doses of glyphosate and evaluation times (Figures 3 and 4). The $F v / F m$ of the control plants remained at approximately 0.63 , whereas in the plants treated with glyphosate ocorred a decrease to 0.43 , especially from $96 \mathrm{HAA}$ (Figure $3 \mathrm{~A}$ ). There were decrease of $50 \%$ in $\triangle \mathrm{F} / \mathrm{Fm}$ ' and ETR in response of the increasing doses of glyphosate and HAA (Figure 3B and Figure 4A). The increasing doses of glyphosate promoted 
increment in NPQ, but these response was more evident at 240 HAA, reaching an increase of $96 \%$ at the highest dose evaluated (Figure 4B).

The contents of the chlorophyll $a, b$ and total decreased in response to the increasing doses of glyphosate and evaluation times (Figure 5A, 5B, 5C, 5D, 5E and 5F). These effects were more pronounced in plants exposed to dose of $1,200 \mathrm{~g}$ a. e. $\mathrm{ha}^{-1}$, with decreases of $23 \%$, de $41 \%$ and $27 \%$ for chlorophyll $a, b$ and total respectively (Figure 5A, 5C and 5E).

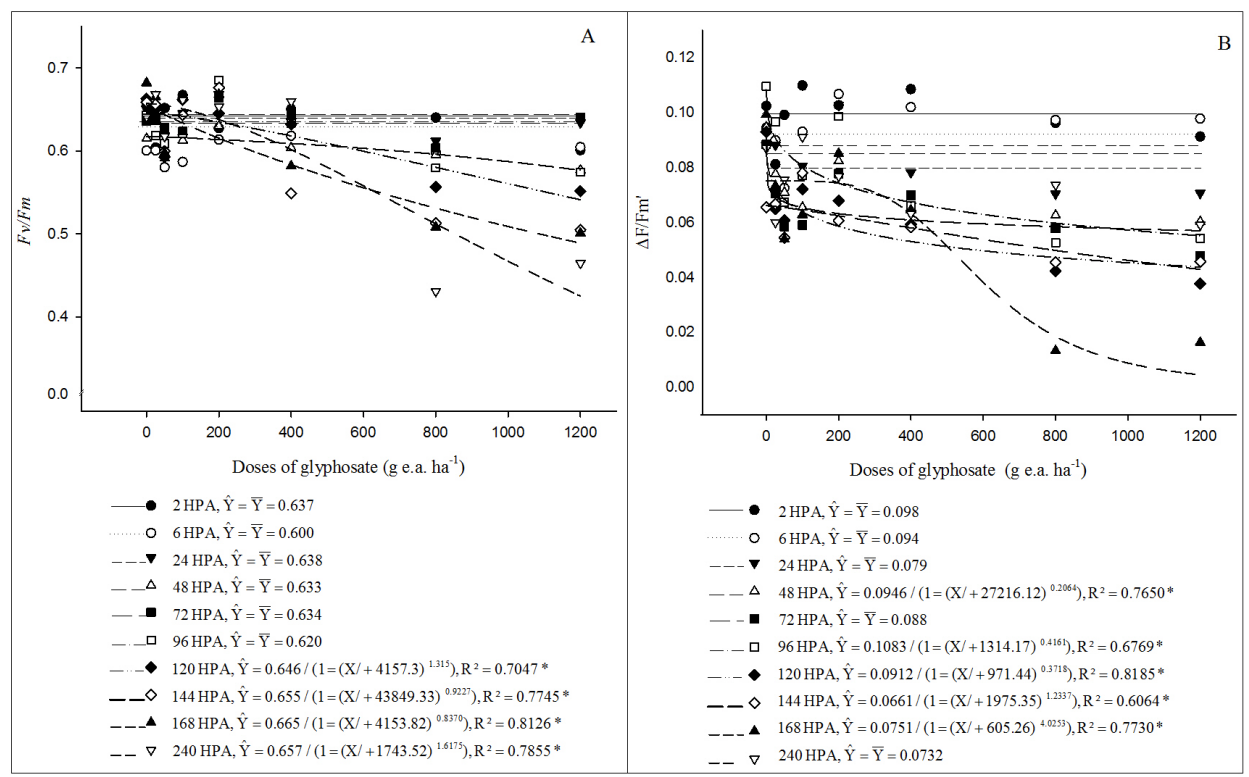

Figure 3. Maximum quantum yield $\left(F_{\gamma} / F_{m} ; \mathrm{A}\right)$ and effective quantum yield of the PSII $\left(\Delta F / F_{m}\right.$ '; $\left.\mathrm{B}\right)$ determined on the leaves of Pouteria torta plants in respose of the interaction between different doses of glyphosate and evaluated at ten different times (HAA). Values are averages $n=4$. Significant by factorial analysis $(* \mathrm{p} \leq 0.05)$.

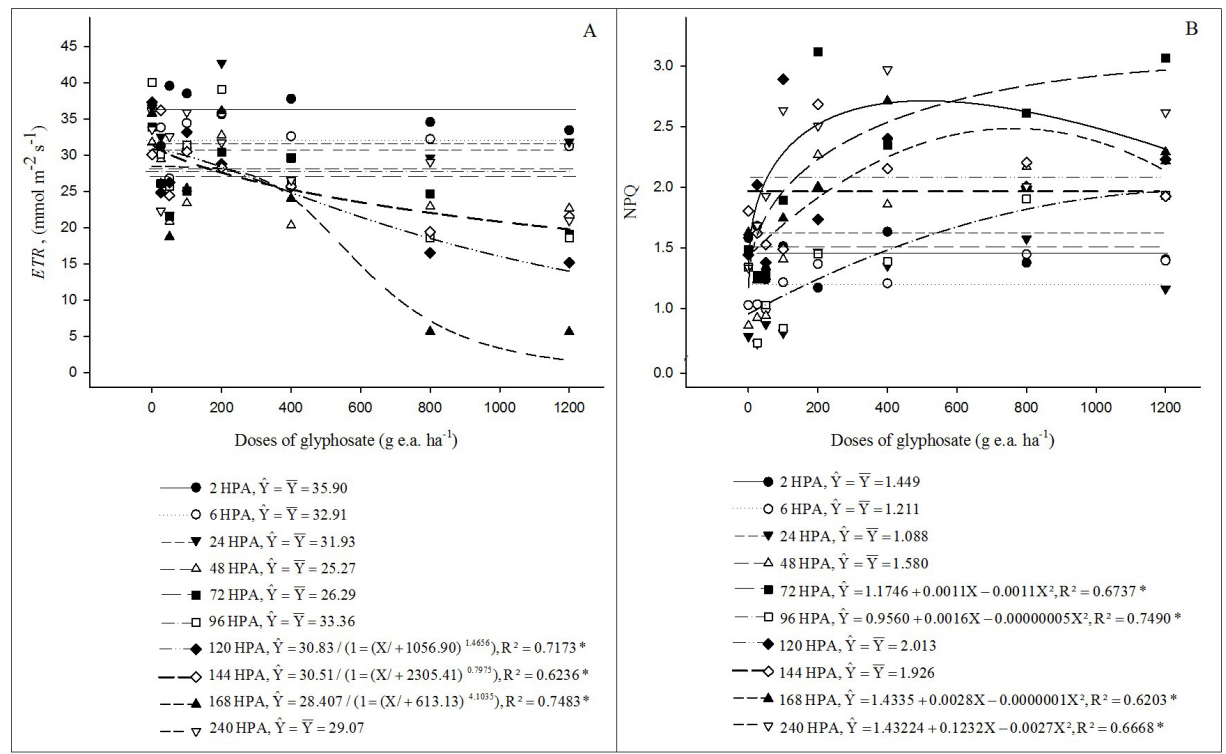

Figure 4. Apparent electron transport rate $(E T R)(\mathrm{A})$ and non-photochemical quenching (NPQ) (B) determined on the leaves of Pouteria torta plants in respose of the interaction between different doses of glyphosate and evaluated and evaluated at ten different times (HAA). Values are averages $n=4$. Significant by factorial analysis $\left({ }^{*} \mathrm{p} \leq 0.05\right)$. 


\subsection{Shikimic acid concentration}

The shikimic acid concentration varied in response to increasing doses of glyphosate, with increases of $40 \%$ in plants exposed to the highest dose (Figure 6A). Regardless of the dose, this increase was observed at 120 HAA (Figure 6B), with accumulation higher than $70 \%$ at 216 HAA (Figure $6 \mathrm{~B}$ ).

\subsection{Visual symptoms}

Plants treated with glyphosate exhibited chlorosis and some necrotic spots, mainly when exposed to the highest doses (Figure 7). The chlorosis occurred in marginal and internerval leaf areas and progressing to the central nerve. Necrotic spots were especially observed in leaf margins and apexes (Figure 7).

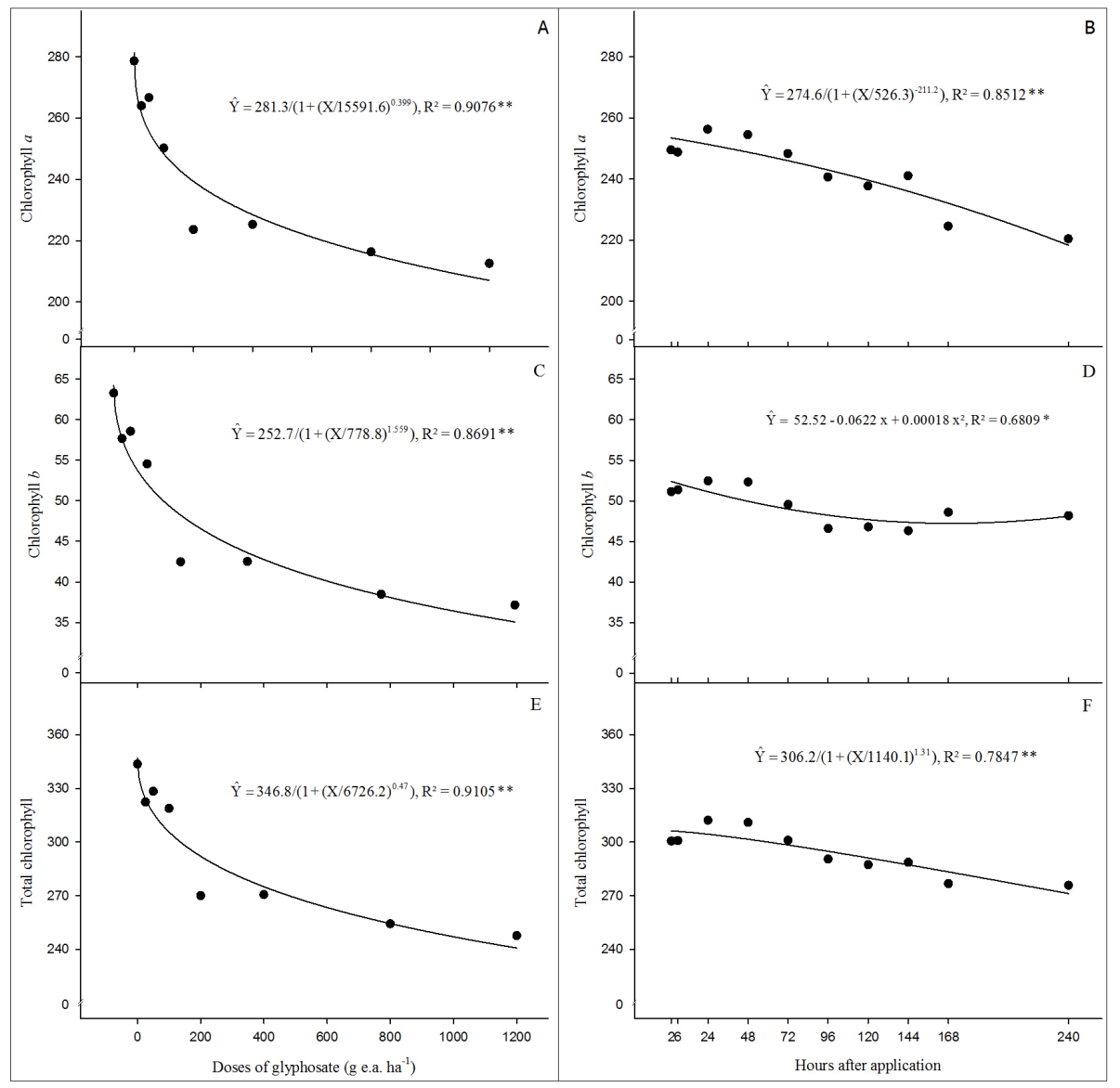

Figure 5. Chlorophyll $a(\mathrm{~A}, \mathrm{~B})$, chlorophyll $b(\mathrm{C}, \mathrm{D})$ and total chorophyll (E, F) determined on the leaves of Pouteria torta plants treated with different doses of glyphosate $(n=32)$ and evaluated at ten different times (HAA) $(n=40)$. Significant by factorial analysis $(* \mathrm{p} \leq 0.05 ; * * \mathrm{p} \leq 0.01)$

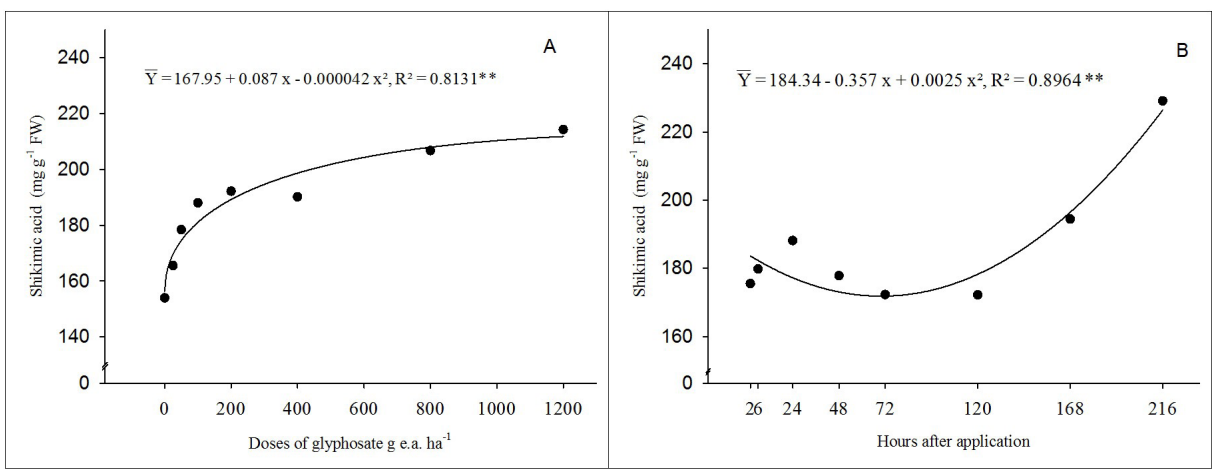

Figure 6. Shikimic acid determined on the leaves of Pouteria torta plants treated with different doses of glyphosate $(\mathrm{A} ; n=32)$ and evaluated at ten different times (HAA) $(\mathrm{B} ; n=20)$. Significant by factorial analysis $(* * \mathrm{p} \leq 0.01)$. 


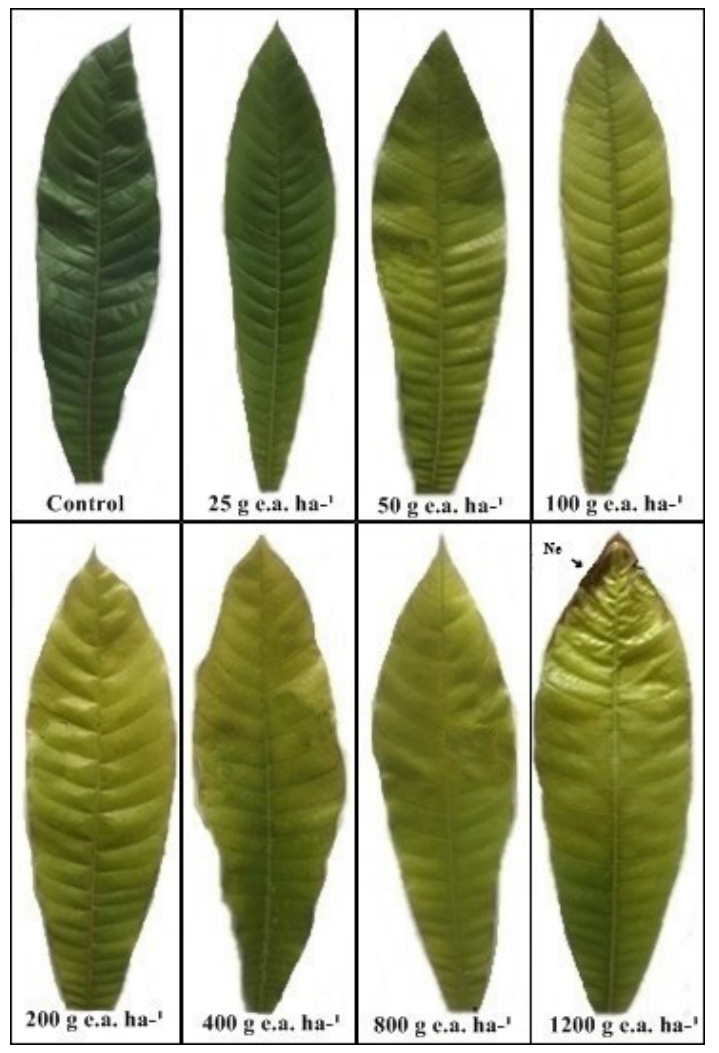

Figure 7. Visual symptoms of toxicity in young leaves of Pouteria torta treated with different doses of glyphosate. $\mathrm{Ne}=$ necrosis.

\section{Discussion}

Glyphosate promoted shikimic acid accumulation, which was possibly induced by the reduction in EPSPs activity. This along with foliar phytotoxicity and several changes in physiological processes indicated high sensitivity to glyphosate. These results provide the first evidence of the potential use of $P$. torta for the evaluation of glyphosate's impact in the Cerrado.

The increase in the shikimic acid content is a typical response by susceptible plants to glyphosate (Buehring et al., 2007; Bonini et al., 2009; Reddy et al., 2008; Schrübbers et al., 2014). This herbicide competes with phosphoenolpyruvate (PEP) at the allosteric site of EPSP (Reade and Cobb, 2002; Carvalho et al., 2012). This enzyme catalyzes the transfer of the enolpyruvyl group from PEP to the 5-hydroxyl group of the shikimate-3-phosphate, producing enolpyruvylshikimate-3-phosphate and inorganic phosphate in the shikimic acid pathway (Franz et al., 1997). Therefore, the suppression of the EPSPs activity reduces the efficiency of the shikimate pathway and increases shikimic acid concentrations. The shikimic acid accumulation in $P$. torta supports its potential as a sensitive and specific biomarker of glyphosate action.

Although the photosynthetic process is not the primary target of glyphosate in plants, some studies have shown a reduction in $A$ triggered by this herbicide (Duke et al.,
2003; Mateos-Naranjo et al., 2009; Orcaray et al., 2010), which supports the results of this study. Yamada and Castro (2007) postulated that the reduced efficiency of gas exchange due to glyphosate is associated with dysregulation of stomatal closure and thus with changes in the opening and closing of stomata. Concurrently with the decrease in $A$, the glyphosate caused a decrease in $g s$ and consequently in $E$. Theses results are more than sufficient to indicate that the decrease in the photosynthetic process occurred, at least in part via stomatal limitations. Similar physiological dysfunctions were found in other studies (Olesen and Cedergreen, 2010; Pereira et al., 2010; Yanniccari et al., 2012).

The increase in the ratio between the internal and external concentrations of $\mathrm{CO}_{2}(\mathrm{Ci} / \mathrm{Ca})$ results from the increase in $\mathrm{CO}_{2}$ concentration in the substomatal chamber. In addition to stomatal limitation, it is assumed that biochemical constraints contributed to decreased efficiency in A in P. torta. Mateos-Naranjo and Perez-Martin (2013) reported that glyphosate decreases the carboxilative efficiency of RuBisCo, possibly by forming reactive oxygen species (Ahsan et al., 2008), which triggers lower efficiency of the Calvin cycle (Watanabe et al., 2013).

$A$ is regarded as the main sink of the absorbed light in chloroplasts, and photooxidative damage can result from the excess energy not used in glyphosate-treated $P$. torta due to drastic decreases in $A$. The activation of the photoprotection mechanism evidenced by the increase in NPQ could contribute to decreasing the energy excess via thermal dissipation. The thermal dissipation is regulated via the xanthophyll cycle and is part of a defense system for avoiding the photoinhibition (Kielak et al., 2011; Marín-Guirao et al., 2013). However, the increased NPQ was not sufficient to mitigate the damage to the photosynthetic apparatus triggered by glyphosate in $P$. torta. This can be supported by the reduction in $F v / F m$, which indicates that damage occurred in the structure of the thylakoids, at least in part due to photooxidative stress (Krause and Weis, 1991).

Concurrent decreases of $50 \%$ in $\Delta \mathrm{F} / \mathrm{Fm}$ ' and ETR of the treated $P$. torta showed that the herbicide affected the process of capture and utilization of the collected energy. These results are consistent with those reported by Mateos-Naranjo et al. (2009), who found severe photochemical limitations in Spartina densiflora treated with glyphosate. Thus, due to the high sensitivity of physiological variables to glyphosate, they could potentially be used as biomarkers of the responses of P. torta to the action of this herbicide.

Photosynthetic pigments are considered as one of the pillars of photosynthetic performance in plants (Tuffi Santos et al., 2009; Yanniccari et al., 2012; Zobiole et al., 2011). Therefore, decreases in the content of chlorophylls triggered by glyphosate at least partly contributed to the decreases in the efficiency of the photosynthetic apparatus. Glyphosate can affect the content of chloroplastid pigments by inhibiting their biosynthesis and by degradation (Moldes et al., 2008). This herbicide can affect the chlorophyll biosynthesis by its chelating action 
with nutrients like nitrogen, magnesium, and manganese, forming slightly soluble metal-glyphosate complexes (Soratto et al., 2004; Zobiole et al., 2011; Mateos-Naranjo and Perez-Martin, 2013), which might have occurred in the P. torta plants.

In conclusion, the results of this study showed that glyphosate greatly affects the physiological performance and the shikimic acid concentration in P. torta, which especially occurred due to biochemical constraints. These metabolic changes resulted in visible damages in the leaves of $P$. torta, which supports the high sensitivity of this species to glyphosate. The physiological changes and visible symptoms triggered by glyphosate in $P$. torta can be used as sensitive biomarkers to this herbicide. Therefore, this plant species has potential to be used as a phytoindicator of glyphosate action. In addition, the results of this study provide the first evidences about the imminent risk of biodiversity loss in Cerrado remnants by glyphosate, in case of indiscriminate use of this herbicide.

\section{Acknowledgements}

The authors wish to thank the Coordenação de Aperfeiçoamento de Pessoal de Nível Superior (CAPES), the Conselho Nacional de Desenvolvimento Científico e Tecnológico (CNPq/ Project SisbiotaBrazil), the Fundo de Financiamento de Estudos de Projetos e Programas, the Fundação de Amparo à Pesquisa do Estado de Goiás (FAPEG), and the Instituto Federal Goiano, Campus Rio Verde, for their financial support.

\section{References}

AHSAN, N., LEE, D.G., LEE, K.W., ALAM, I., LEE, S.H., BAHK, J.D. and LEE, B.H., 2008. Glyphosate-induced oxidative stress in rice leaves revealed by proteomic approach. Plant Physiology and Biochemistry, vol. 46, no. 12, pp. 1062-1070. PMid:18755596. http://dx.doi.org/10.1016/j.plaphy.2008.07.002.

BEUCHLE, R., GRECCHI, R.C., SHIMABUKURO, Y.E., SELIGER, R., EVA, H.D., SANO, E. and ACHARD, F., 2015. Land cover changes in the Brazilian Cerrado and Caatinga biomes from 1990 to 2010 based on a systematic remote sensing sampling approach. Applied Geography, vol. 58, pp. 116-127. http://dx.doi. org/10.1016/j.apgeog.2015.01.017.

BILGER, W. and BJÖRKMAN, O., 1990. Role of xanthophyll cycle in photoprotection elucidated by measurements of light induced absorbance changes, fluorescence and photosynthesis in leaves of Hedera canariensis. Photosynthesis Research, vol. 25, no. 3, pp. 173-185. PMid:24420348. http://dx.doi.org/10.1007/ BF00033159.

BILGER, W., SCHREIBER, U. and BOCK, M., 1995. Determination of the quantum efficiency of photosystem II and of non-photochemical quenching of chlorophyll fluorescence in the field. Oecologia, vol. 102, no. 4, pp. 425-432. PMid:28306885. http://dx.doi.org/10.1007/BF00341354.

BØHN, T., CUHRA, M., TRAAVIK, T., SANDEN, M., FAGAN, J. and PRIMICERIO, R., 2014. Compositional differences in soybeans on the market: glyphosate accumulates in Roundup
Ready GM soybeans. Food Chemistry, vol. 153, pp. 207-215. PMid:24491722. http://dx.doi.org/10.1016/j.foodchem.2013.12.054.

BOLETI, A.P.A., FREIRE, M.G.M., COELHO, M.B., SILVA, W., BALDASSO, P.A., GOMES, V.M., MARANGONI, S., NOVELLO, J.C. and MACEDO, M.L.R., 2007. Insecticidal and antifungal activity of a protein from Pouteria torta seeds with lectin-like properties. Journal of Agricultural and Food Chemistry, vol. 55, no. 7, pp. 2653-2658. PMid:17348680. http:// dx.doi.org/10.1021/jf0636317.

BONINI, E.A., FERRARESE, M.L.L., MARCHIOSI, R., ZONETTI, P.C. and FERRARESE-FILHO, O., 2009. A simple chromatographic assay to discriminate between glyphosate-resistant and susceptible soybean (Glycine max) cultivars. European Journal of Agronomy, vol. 31, no. 3, pp. 173-176. http://dx.doi. org/10.1016/j.eja.2009.03.006.

BOUTIN, C., AYA, K.L., CARPENTER, D., THOMAS, P.J. and ROWLAND, O., 2012. Phytotoxicitytesting for herbicide regulation: shortcomings in relation to biodiversity andecosystem services in agrarian systems. The Science of the Total Environment, vol. 415, pp. 79-92. PMid:21621821. http://dx.doi.org/10.1016/j. scitotenv.2011.04.046

BOUTIN, C., STRANDBERGB, B., CARPENTER, D., MATHIASSEN, S.K. and THOMAS, P.J., 2014. Herbicide impact on non-target plant reproduction: What are the toxicological and ecological implications? Environmental Pollution, vol. 185, pp. 295-306. PMid:24316067. http://dx.doi.org/10.1016/j. envpol.2013.10.009.

BUEHRING, N.W., MASSEY, J.H. and REYNOLDS, D.B., 2007. Shikimic acid accumulation in field-grown corn (Zea mays) following simulated glyphosate drift. Journal of Agricultural and Food Chemistry, vol. 55, no. 3, pp. 819-824. PMid:17263480. http://dx.doi.org/10.1021/jf062624f.

CARVALHO, J.L.N., RAUCCI, G.S., FRAZÃO, L.A., CERRI, C.E.P.C., BERNOUX, M. and CERRI, C.C., 2014. Crop-pasture rotation: a strategy to reduce soil greenhouse gas emissions in the Brazilian Cerrado. Agriculture, Ecosystems \& Environment, vol. 183, pp. 167-175. http://dx.doi.org/10.1016/j.agee.2013.11.014.

CARVALHO, L.B., ALVES, P.L.C.A., GONZALEZ-TORRALVA, F., CRUZ-HIPOLITO, H.E., ROJANO-DELGADO, A.M., PRADO, R., GIL-HUMANES, J. and BARRO, F., 2012. Pool of resistance mechanisms to glyphosate in Digitaria insularis. Journal of Agricultural and Food Chemistry, vol. 60, no. 2, pp. 615-622. PMid:22175446. http://dx.doi.org/10.1021/jf204089d.

DAYAN, F.E. and ZACCARO, M.L.M., 2012. Chlorophyll fluorescence as a marker for herbicide mechanisms of action. Pesticide Biochemistry and Physiology, vol. 102, no. 3, pp. 189197. http://dx.doi.org/10.1016/j.pestbp.2012.01.005.

DAYAN, F.E., OWENS, D.K., CORNIANI, N., SILVA, F.M.L., WATSON, S.B., HOWELL, J.L. and SHANER, D.L., 2015. Biochemical markers and enzyme assays for herbicide mode of action and resistance studies. Weed Science, vol. 63, no. 1, pp. 23-63. http://dx.doi.org/10.1614/WS-D-13-00063.1.

DE-TEMMERMAN, L., BELL, J.N.B., GARREC, J.P., KLUMPP, A., KRAUSE, G.H.M. and TONNEIJCK, A.E.G., 2004. Biomonitoring of air pollution with plants e considerations for the future. In: A. KLUMPP, W. ANSEL, G. KLUMPP, eds. Urban air pollution, bioindication and environmental awareness. Gottingen: Cuvillier Verlag, pp. 337-373.

DUKE, S.O., BAERSON, S.R. and RIMANDO, A.M., 2003. Glyphosate. In: J.R. PLIMMER, D.W. GAMMON, N.N. 
RANSDALE, eds. Encyclopedia of Agrochemicals. New York: John Wiley and Sons. http://dx.doi.org/10.1002/047126363X.agr119.

EGAN, J.F., BOHNENBLUST, E., GOSLEE, S., MORTENSEN, D. and TOOKER, J., 2014. Herbicide drift can affect plant and arthropod communities. Agriculture, Ecosystems \& Environment, vol. 185, pp. 77-87. http://dx.doi.org/10.1016/j.agee.2013.12.017.

FRANCO-BERNARDES, M.F., MASCHIO, L.R., AZEREDOOLIVEIRA, M.T.V. and ALMEIDA, E.A., 2015. The use of biomarkers to study the effects of the mixture of diuron and hexazinone on small and large $O$. niloticus. Ecotoxicology and Environmental Contamination, vol. 10, no. 1, pp. 83-92. http:// dx.doi.org/10.5132/eec.2015.01.12.

FRANÇOSO, R.D., BRANDÃO, R., NOGUEIRA, C.C., SALMONA, Y.B., MACHADO, R.B. and COLLI, G.R., 2015. Habitat loss and the effectiveness of protected areas in the Cerrado Biodiversity Hotspot. Natureza \& Conservação, vol. 13, no. 1, pp. 35-40. http://dx.doi.org/10.1016/j.ncon.2015.04.001.

FRANZ, J.E., MAO, M.K. and SIKORSKI, J.A., 1997. Glyphosate: a unique global herbicide. Washington: American Chemical Society. $653 \mathrm{p}$

GAITONDE, M.K. and GORDON, M., 1958. A microchemical method for the detection and determination of shikimic acid. The Journal of Biological Chemistry, vol. 230, no. 2, pp. 1043-1050. PMid:13525420.

GENTY, B., BRIANTAIS, J.M. and BAKER, N.R., 1989. The relationship between the quantum yield of photosynthetic electron transport and quenching of chlorophyll fluorescence. Biochimica et Biophysica Acta, vol. 990, no. 01, pp. 87-92. http://dx.doi. org/10.1016/S0304-4165(89)80016-9.

HATTAB, S., HATTAB, S., FLORES-CASSERES, M.L., BOUSSETTA, H., DOUMAS, P., HERNANDEZ, L.E. and BANNI, M., 2016. Characterization of lead-induced stress molecular biomarkers in Medicago sativa plants. Environmental and Experimental Botany, vol. 123, pp. 1-12. http://dx.doi. org/10.1016/j.envexpbot.2015.10.005.

KIELAK, E., SEMPRUCHB, C., MIODUSZEWSKA, H., KLOCEK, J. and LESZCZYŃSKI, B., 2011. Phytotoxicity of Roundup Ultra 360 SL in aquatic ecosystems: Biochemical evaluation with duckweed (Lemna minor L.) as a model plant. Pesticide Biochemistry and Physiology, vol. 99, no. 3, pp. 237243. http://dx.doi.org/10.1016/j.pestbp.2011.01.002.

KRAUSE, G.H. and WEIS, E., 1991. Chlorophyll fluorescence and photosynthesis: the basics. Annual Review of Plant Biology, vol. 42, no. 1, pp. 313-349. http://dx.doi.org/10.1146/annurev. pp.42.060191.001525.

LAISK, A. and LORETO, F., 1996. Determining photosynthetic parameters from leaf $\mathrm{CO}_{2}$ exchange and chlorophyll fluorescence. Plant Physiology, vol. 110, no. 3, pp. 903-912. PMid:12226229. http://dx.doi.org/10.1104/pp.110.3.903.

MACFARLANE, G.R., 2003. Chlorophyll a fluorescence as a potential biomarker of zinc stress in the grey mangrove, Avicennia marina (Forsk.) Vierh. Bulletin of Environmental Contamination and Toxicology, vol. 70, no. 1, pp. 90-96. PMid:12478429. http:// dx.doi.org/10.1007/s00128-002-0160-0.

MACHADO, A.F.L., FERREIRA, L.R., SANTOS, L.D.T., FERREIRA, F.A., VIANA, R.G., MACHADO, M.S. and FREITAS, F.C.L., 2010. Eficiência fotossintética e uso da água em plantas de eucalipto pulverizadas com glyphosate. Planta
Daninha, vol. 28, no. 02, pp. 319-327. http://dx.doi.org/10.1590/ S0100-83582010000200011.

MANCUSO, M.A.C., NEGRISOLI, E. and PERIM, L., 2011. Efeito residual de herbicidas no solo ("Carryover"). Revista Brasileira de Herbicidas, vol. 10, no. 02, pp. 151-164. http:// dx.doi.org/10.7824/rbh.v10i2.106.

MARÍN-GUIRAO, L., RUIZ, J.M., SANDOVAL-GIL, J.M., BERNARDEAU-ESTELLER, J., STINCO, C.M. and MELÉNDEZMARTÍNEZ,A., 2013. Xanthophyll cycle-related photoprotective mechanism in the Mediterranean seagrasses Posidonia oceânica and Cymodocea nodosa under normal and stressful hypersaline conditions. Aquatic Botanic, vol. 109, pp. 14-24. http://dx.doi. org/10.1016/j.aquabot.2013.03.006.

MARRIS, E., 2005. Conservation in Brazil: the forgotten ecosystem. Nature, vol. 437, no. 7061, pp. 944-945. PMid:16222267. http:// dx.doi.org/10.1038/437944a.

MARWITZ, A., LADEWIG, E. and MÄRLÄNDER, B., 2014. Response of soil biological activity to common herbicide strategies in sugar beet cultivation. European Journal of Agronomy, vol. 54, pp. 97-106. http://dx.doi.org/10.1016/j.eja.2013.12.003.

MATEOS-NARANJO, E. and PEREZ-MARTIN, A., 2013. Effects of sub-lethal glyphosate concentrations on growth and photosynthetic performance of non-target species. Bolboschoenus maritimus. Chemosphere, vol. 93, no. 10, pp. 2631-2638. PMid:24161579. http://dx.doi.org/10.1016/j.chemosphere.2013.09.094.

MATEOS-NARANJO, E., REDONDO-GÓMEZ, S., COX, L., CORNEJO, J. and FIGUEROA, M.E., 2009. Effectiveness of glyphosate and imazamox on the control of the invasive cordgrass Spartina densiflora. Ecotoxicology and Environmental Safety, vol. 72, no. 6, pp. 1694-1700. PMid:19577295. http://dx.doi. org/10.1016/j.ecoenv.2009.06.003.

MOLDES, C.A., MEDICI, L.O., ABRAHÃO, O.S., TSAI, S.M. and AZEVEDO, R.A., 2008. Biochemical responses of glyphosate resistant and susceptible soybean plants exposed to glyphosate. Acta Physiologiae Plantarum, vol. 30, no. 04, pp. 469-479. http:// dx.doi.org/10.1007/s11738-008-0144-8.

MYERS, N.R.A., MITTERMEIER, C.G., FONSECA, G.A.B. and KENT, J., 2000. Biodiversity hotspots for conservation priorities. Nature, vol. 403, no. 6772, pp. 853-858. PMid:10706275. http:// dx.doi.org/10.1038/35002501.

NUNES, A.L. and VIDAL, R.A., 2009. Seleção de plantas quantificadoras de herbicidas residuais. Pesticidas: Revista de Ecotoxicologia e Meio Ambiente, vol. 19, pp. 19-28.

OLESEN, C.F. and CEDERGREEN, N., 2010. Glyphosate uncouples gas exchange and chlorophyll fluorescence. Pest Management Science, vol. 66, no. 5, pp. 536-542. PMid:20127759. http:// dx.doi.org/10.1002/ps.1904.

ORCARAY, L., IGAL, M., MARINO, D., ZABALZA, A. and ROYUELA, M., 2010. The possible role of quinate in the mode of action of glyphosate and acetolactate synthase inhibitors. Pest Management Science, vol. 66, no. 3, pp. 262-269. PMid:19918955. http://dx.doi.org/10.1002/ps.1868.

PEREIRA, M.R.R., RODRIGUES, A.C.P., COSTA, N.V., MARTINS, D., KLAR, A.E. and SILVA, M.R., 2010. Efeito da deriva de glyphosate sobre algumas características fisiológicas em plantas de eucalipto. Interciencia, vol. 35, pp. 279-283.

PERFEITO, J.P., SANTOS, M.L., LÓPEZ, K.S.E., PAULA, J.E. and SILVEIRA, D., 2005. Characterization and biological properties of Pouteria torta extracts: a preliminary study. Revista 
Brasileira de Farmacognosia, vol. 15, no. 03, pp. 183-186. http:// dx.doi.org/10.1590/S0102-695X2005000300002.

POWER, E.F., KELLY, D.L. and STOUT, J.C., 2013. The impacts of traditional and novel herbicie application methods on target plants, non-target plants and production in intensive grasslands. Weed Research, vol. 53, no. 02, pp. 131-139. http://dx.doi. org/10.1111/wre.12009.

PRASAD, S.M., SINGH, A. and SINGH, P., 2015. Physiological, biochemical and growth responses of Azolla pinnata to chlorpyrifos and cypermethrin pesticides exposure: a comparative study. Chemistry and Ecology, vol. 31, no. 03, pp. 285-298. http:// dx.doi.org/10.1080/02757540.2014.950566.

PROCÓPIO, S.O., CARMO, M.L., PIRES, F.R., CARGNELUTTIFILHO, A., BRAZ, G.B.P., SILVA, W.F.P., BARROSO, A.L.L., SILVA, G.P., CARMO, E.L., BRAZ, A.J.B.P. and PACHECO, L.P., 2009. Efeito da densidade populacional de Panicum maximum (cultivar Tanzânia) na fitorremediação de solo contaminado com o herbicida picloram. Semina: Ciências Agrárias, vol. 30, no. 02, pp. 295-304. http://dx.doi.org/10.5433/1679-0359.2009v30n2p295.

RASCHER, U., LIEBIG, M. and LÜTTGE, U., 2000. Evaluation of instant lightresponse curves of chlorophyll fluorescence parameters obtained with a portable chlorophyll fluorometer on site in the field. Plant, Cell \& Environment, vol. 23, no. 12, pp. 1397-1405. http://dx.doi.org/10.1046/j.1365-3040.2000.00650.x.

READE, J.P.H. and COBB, A.H., 2002. Herbicides: modes of action and metabolism. In: R.E.L. NAYLOR, ed. Weed management handbook. 9th ed. Oxford: British Crop Protection Council, Blackwell Science, pp. 134-170.

REDDY, K.N., RIMANDO, A.M., DUKE, S.O. and NANDULA, V.K., 2008. Aminomethylphosphonic acid accumulation in plant species treated with glyphosate. Journal of Agricultural and Food Chemistry, vol. 56, no. 6, pp. 2125-2130. PMid:18298069. http:// dx.doi.org/10.1021/jf072954f.

SCHRÜBBERS, L.C., VALVERDE, B.E., SøRENSEN, J.C. and CEDERGREEN, N., 2014. Glyphosate spray drift in Coffea arabica - Sensitivity of coffee plants and possible use of shikimic acid as a biomarker for glyphosate exposure. Pesticide Biochemistry and Physiology, vol. 115, pp. 15-22. PMid:25307461. http://dx.doi. org/10.1016/j.pestbp.2014.08.003.

SIHTMÄE, M., BLINOVA, I., KÜNNIS-BERES, K., KANARBIK, L., HEINLAAN, M. and KAHRU, A., 2013. Ecotoxicological effects of different glyphosate formulations. Applied Soil Ecology, vol. 72, pp. 215-224. http://dx.doi.org/10.1016/j.apsoil.2013.07.005.

SILVA, J.S., 2010. Considerações sobre a ocupação do Cerrado na microrregião do sudoeste de Goiás: modernização versus degradação. Revista em Agronegócios e Meio Ambiente, vol. 3, no. 1, pp. 89-99.

SILVA, J.F., FARINAS, M.R., FELFILI, J.M. and KLINK, C.A., 2006. Spatial heterogeneity, land use and conservation in the Cerrado region of Brazil. Journal of Biogeography, vol. 33, no. 03, pp. 536-548. http://dx.doi.org/10.1111/j.1365-2699.2005.01422.x.

SIMMONS, W.J., 2013. Bowman v. Monsanto and the protection of patented replicative biologic technologies. Nature Biotechnology, vol. 31, no. 7, pp. 602-606. PMid:23839143. http://dx.doi. org/10.1038/nbt.2625.

SINGH, B.K. and SHANER, D.L., 1998 [viewed 22 May 2016]. Rapid determination of glyphosate injury to plants and identification of glyphosate-resistant plants. Weed Technology [online], vol. 12, no. 3, pp. 527-530. Available from: http://www. jstor.org/stable/3988945

SORATTO, R.P., CARVALHO, M.A.C. and ARF, O., 2004. Teor de clorofila e produtividade do feijoeiro em razão da adubação nitrogenada. Pesquisa Agropecuária Brasileira, vol. 39, no. 9, pp. 895-901. http://dx.doi.org/10.1590/S0100-204X2004000900009.

TUFFI SANTOS, L.D., SANT'ANNA-SANTOS, B.F., MEIRA, R.M.S.A., FERREIRA, F.A., TIBURCIO, R.A.S. and MACHADO, A.F.L., 2009. Leaf anatomy and morphometry in three eucalypt clones treated with glyphosate. Brazilian Journal of Biology = Revista Brasileira de Biologia, vol. 69, no. 1, pp. 129-136. http:// dx.doi.org/10.1590/S1519-69842009000100016.

VAN KOOTEN, O. and SNEL, J.F.H., 1990. The use of chlorophyll fluorescence nomenclature in plant stress physiology. Photosynthesis Research, vol. 25, no. 3, pp. 147-150. PMid:24420345. http:// dx.doi.org/10.1007/BF00033156.

WANG, H., HE, L., SONG, J., CUI, W., ZHANG, Y., JIA, C., FRANCIS, D., ROGERS, H.J., SUN, L., TAI, P., HUI, X., YANG, Y. and LIU, W., 2016. Cadmium-induced genomic instability in Arabidopsis: Molecular toxicological biomarkers for early diagnosis of cadmium stress. Chemosphere, vol. 150, pp. 258-265. PMid:26907594. http://dx.doi.org/10.1016/j. chemosphere.2016.02.042.

WATANABE, M., HOSHIKA, Y., INADA, N., WANG, X., MAO, Q. and KOIKE, T., 2013. Photosynthetic traits of Siebold's beech and oak saplings grown under free air ozone exposure in northern Japan. Environmental Pollution, vol. 174, pp. 50-56. PMid:23246746. http://dx.doi.org/10.1016/j.envpol.2012.11.006.

YAMADA, T. and CASTRO, P.R., 2007. Efeitos do glyphosate nas plantas: implicações fisiológicas e agronômicas. Informações Agronômica, vol. 119, pp. 1-24.

YANNICCARI, M., ISTILART, C., GIMÉNEZ, J.O., ACCIARESI, H. and CASTRO, A.M., 2012. Efecto del glyphosate sobre el crecimiento y acumulación de azúcares libres en dos biotipos de Lolium perenne de distinta sensibilidad al herbicida. Planta Daninha, vol. 30, no. 1, pp. 155-164. http://dx.doi.org/10.1590/ S0100-83582012000100018.

ZHAO, T., LIN, C.Y. and SHEN, Z.C., 2011. Development of Transgenic Glyphosate-Resistant Rice with G6 Gene Encoding 5-Enolpyruvylshikimate-3-Phosphate Synthase. Agricultural Sciences in China, vol. 10, no. 9, pp. 1307-1312. http://dx.doi. org/10.1016/S1671-2927(11)60123-5.

ZOBIOLE, L.H.S., KREMER, R.J., OLIVEIRA JUNIOR, J.R.R.S. and CONSTANTIN, J., 2011. Glyphosate affects chlorophyll, nodulation and nutrient accumulation of "second generation" glyphosate-resistant soybean (Glycine max L.). Pesticide Biochemistry and Physiology, vol. 99, no. 1, pp. 53-60. http:// dx.doi.org/10.1016/j.pestbp.2010.10.005. 